Jurnal Lensa Mutiara Komunikasi Vol. 5, No. 1 (Juni 2021) 110-122

ISSN 2579-8332 (Online) |http://u.lipi.go.id/1487661056

\title{
Strategi Akomodasi Komunikasi dalam Proses Pembelajaran Secara Daring Selama Masa Pandemi Covid-19
}

\author{
Astrid Kusuma Rahardaya ${ }^{1 *}$, Irwansyah ${ }^{1}$ \\ ${ }^{1}$ Department of Communication Science, Universitas Indonesia \\ Jl. Margonda Raya, Pondok Cina, Kecamatan Beji, Kota Depok, Jawa Barat \\ E-mail: ${ }^{1}$ astrid.k01@ui.ac.id, ${ }^{1}$ irwansyah09@ui.ac.id
}

Received: Januari 2021; Accepted: April; 2021; Published: Juni 2021

\begin{abstract}
This study aims to determine the communication accommodation strategy in the online learning process during the Covid-19 pandemic which occurred in teaching and learning activities in English at the elementary, junior high, senior high school and vocational school levels in Jakarta and also to determine the obstacles in communication accommodation strategies in the learning process. This study uses an exploratory method with Communication Accommodation Theory as a reference for data analysis used to discuss the possibility of a new phenomenon that has not been found in previous research and to examine phenomena in the context of real life. The results showed that the convergence strategy in communication accommodation in the online learning process during the Covid-19 pandemic was mostly carried out by English teachers at the SD, SMP, SMA, and SMK levels. This is to show that the teaching and learning delivery process is easier for students to understand and accept during online learning. In addition, based on the results of the interview, the researcher found that there were obstacles and impacts that were felt in the teaching and learning process taking place. Students tend to be passive compared to face-to-face learning.
\end{abstract}

Keywords: Communication Accommodation Theory; Communication Accommodation Strategy; Online Learning.

\begin{abstract}
Abstrak
Penelitian ini bertujuan untuk mengetahui strategi akomodasi komunikasi dalam proses pembelajaran secara daring selama masa pandemi Covid-19 yang terjadi pada kegiatan belajar mengajar pelajaran bahasa Inggris di tingkat SD, SMP, SMA dan SMK di Jakarta serta untuk mengetahui kendala dalam strategi akomodasi komunikasi dalam proses pembelajaran berlangsung. Penelitian ini menggunakan metode eksploratif dengan Teori Akomodasi Komunikasi sebagai acuan analisis data yang digunakan untuk membahas kemungkinan suatu fenomena baru yang belum ditemukan dalam penelitian sebelumnya dan meneliti fenomena di dalam konteks kehidupan nyata. Hasil penelitian menunjukan bahwa strategi konvergensi dalam akomodasi komunikasi dalam proses pembelajaran secara daring selama masa pandemi Covid-19 lebih banyak dilakukan oleh guru bahasa inggris tingkat SD, SMP, SMA, dan SMK. Hal tersebut dilakukan agar proses penyampaian belajar mengajar lebih mudah dimengerti dan diterima oleh murid selama pembelajaran daring berlangsung. Selain itu, berdasarkan hasil wawancara peneliti menemukan terdapat hambatan dan dampak yang dirasakan dalam proses kegiatan belajar mengajar berlangsung. Murid cenderung pasif dibandingkan dengan proses pembelajaran secara tatap muka.
\end{abstract}

Kata Kunci: Teori Akomodasi Komunikasi; Strategi Akomodasi Komunikasi; Pembelajaran Daring.

doi: https://doi.org/10.51544/jlmk.v5i1.1662

(c) 2021 Jurnal Lensa Mutiara Komunikasi. This is an open access article under the CC BY-SA license

Website: http://e-journal.sari-mutiara.ac.id/index.php/JLMI/

http://e-journal.sari-mutiara.ac.id 


\section{PENDAHULUAN}

Pandemi Coronavirus Disease atau yang dikenal dengan Covid-19 telah melanda dunia khususnya Indonesia selama hampir setahun belakang. Sejauh ini, pandemic Covid-19 yang terjadi di tingkat global maupun dalam negeri masih memiliki risiko penularan dan dampak yang sangat tinggi. Menurut data dari Komite Penanganan Covid-19 dan Pemulihan Ekonomi Nasional hingga awal Januari 2021, jumlah kasus positif Covid-19 di Indonesia adalah sebanyak 765,350 sejak dilaporkan kasus pertama yaitu pada 2 Maret 2020. Indonesia menduduki peringkat pertama dengan kasus tertinggi di ASEAN (Covid19.go.id, 2020). Selama vaksin Covid-19 masih dalam proses pengembangan, seluruh dunia termasuk Indonesia dihadapkan oleh kenyataan untuk dapat bersiap diri untuk hidup secara berdampingan dengan Covid-19. Berkaitan dengan hal tersebut, diperlukannya pedoman atau panduan dalam upaya pengendalian dan pencegahan Covid-19 agar masyarakat dapat tetap melaksanakan aktivitas sehari-hari. Pemerintah Indonesia membuat dan menyusun pedoman pengendalian dan pencegahan Covid-19 sesuai dengan rekomendasi yang diberikan oleh World Health Organization (WHO) yang disesuaikan dengan perkembangan situasi Covid-19 serta sesuai dengan peraturan undangundang yang berlaku di Indonesia (Fatmawati 2020).

Berdasarkan Surat Keputusan yang dikeluarkan oleh Kementerian Kesehatan RI No. HK.01.07/Menkes/413/2020 pada tanggal 13 Juli 2020 mengenai Pendoman Pencegahan dan Pengendalian Covid-19 bahwa Covid-19 telah dinyatakan oleh WHO sebagai pandemic global dan suatu jenis penyakit yang mengakibatkan kematian dan kerugian ekonomi negara yang cukup besar, maka Pemerintah melakukan upaya dalam mencegah bertambahnya penyebaran dan upaya mengendalikan virus tersebut dengan cara mewajibkan masyarakat untuk selalu menggunakan masker saat beraktivitas, melakukan physical distancing atau menjaga jarak satu sama lain minimal 1 (satu) meter, rajin mencuci tangan menggunakan air dan sabun cuci tangan atau hand-sanitizer, meminimalisir kegiatan di luar rumah dan menghindari pusat-pusat keramaian (Menkes 2020).

Penyebaran virus Covid-19 dan peningkatan jumlah kasus yang berlangsung sangat cepat dan sudah hampir menyebar ke seluruh wilayah di Indonesia, membuat pemerintah memberlakukan Pembatasan Sosial Berskala Besar (PSBB) pada beberapa wilayah yang dinyatakan sebagai zona merah agar dapat menekan laju percepatan penyebaran Covid-19. Kebijakan PSBB tersebut membuat aktivitas-aktivitas masyarakat menjadi terbatas, seperti jumlah transportasi umum dibatasi dan diberlakukannya pembatasan waktu jam operasional pusat perbelanjaan, tempat hiburan dan rekreasi. Cepatnya penyebaran virus Covid-19 menyebabkan kekhawatiran dari masyarakat dan memiliki dampak cukup besar di berbagai sektor kehidupan, antara lain sektor ekonomi, perdagangan, pariwisata, industri, hingga sektor pendidikan (Ristyawati 2020).

Dalam sektor ekonomi, berbagai macam kegiatan dan aktivitas mulai dari kegiatan pariwisata hingga perdagangan terpaksa harus memberhentikan usahanya dan memberhentikan karyawannya. Hal tersebut berkaitan dengan upaya dalam mendukung Pemerintah untuk menerapkan social dan physical distancing yang mana memberikan dampak langsung terhadap perekonomian negara dikarenakan terjadinya penurunan kegiatan-kegiatan di luar rumah. Salah satu contohnya adalah Pemerintah membatasi jam-jam operasional pusat perbelanjaan sehingga pendapatan akan menurun secara otomatis. Berkaitan dengan hal tersebut, semakin banyak masyarakat yang mengurangi aktivitas di luar rumah, begitu pula dalam kegiatan berpariwisata. Mayoritas masyarakat tidak berani untuk berlibur dan menginap di tempat wisata dikarenakan untuk mencegah tertularnya virus Covid-19. Hal itu tentu berdampak pada tutupnya sejumlah 
hotel di sejumlah daerah wisata di kota-kota besar di Indonesia seperti Jogjakarta, Bali dan Jakarta (Dwina 2020).

Selain sektor ekonomi, pariwisata dan perdagangan yang terkena dampak dari Covid-19. Sektor lain yang juga terkena dampaknya secara keseluruhan adalah sektor pendidikan. Dalam sektor pendidikan, menurut data UNESCO (2020) menyatakan bahwa akibat Covid-19, sebanyak 1,5 miliar siswa dan 63 juta guru dari tingkat dasar sampai menengah di 191 negara di seluruh dunia tertular wabah Covid-19. Hal ini membuat pemerintah mengambil langkah untuk menetapkan kebijakan menutup sekolah dan memberhentikan kegiatan belajar mengajar tatap muka secara langsung atau offline. Hal tersebut berlaku mulai dari kegiatan belajar mengajar usia dini, tingkat Sekolah Dasar, Sekolah Menengah Pertama, Sekolah Menengah Atas hingga Perguruan Tinggi. Sebagai ganti dari kebijakan penutupan tersebut, pemerintah mengharuskan seluruh sekolah maupun instansi pendidikan untuk menerapkan kegiatan Belajar Dari Rumah (BDR) dengan memberlakukan metode pembelajaran jarak jauh secara daring (Fahmi 2020).

Berbagai model dan cara pembelajaran yang digunakan oleh guru atau pendidik dalam membantu peserta didik belajar dari rumah secara daring yang mana dalam proses pembelajarannya melalui media dan koneksi internet. Melalui media internet, proses pembelajaran dapat diperoleh secara cepat. Jarak bukan lagi menjadi kendala dan halangan bagi murid untuk memperoleh ilmu pengetahuan dan pembelajaran (Hia Setiamenda 2018). Terlebih lagi, seiring dengan perkembangan teknologi dan internet, munculnya berbagai macam aplikasi pembelajaran yang dapat digunakan oleh guru dan muridnya dalam kegiatan belajar mengajar. Proses pembelajaran secara daring ini menciptakan sebuah pembelajaran baru yang mana peran pendidik adalah sebagai seorang fasilitator dalam memberikan bahan materi ajar dan diharapkan siswa sebagai peserta aktif dalam proses belajar mengajar. Maka dari itu, seorang pendidik diharapkan dapat membuat proses belajar mengajar secara daring ini dapat diterima oleh siswa dan berupaya agar bahan materi ajar dapat tersampaikan dengan baik kepada para siswa (Anugrahana 2020).

Efektivitas penerimaan pesan dalam belajar mengajar tidak menjadi satu-satunya ukuran. Terdapat beberapa ukuran lain yang dijadikan standar baik atau tidaknya dari komunikasi yang terjadi, seperti bagaimana cara penyampaian pesan dalam proses belajar mengajar, bagaimana bahasa yang dipilih untuk menyampaikan pesan serta konteks dalam penyampaian pesan yang mencakup waktu serta melalui media apa dalam menyampaikan pesan tersebut (Cathrin 2020). Maka dari itu, dalam upaya agar bahan materi belajar mengajar dapat tersampaikan dengan baik kepada para siswa, maka diperlukannya strategi komunikasi belajar mengajar yang baik. Howard Giles dan koleganya mengemukakan bahwa dalam melakukan komunikasi, komunikator biasanya melakukan penyesuaian dalam berinteraksi, baik penyesuaian nada bicara atau perilaku lawan bicara untuk mengakomodasi lawan bicaranya. Selain itu dapat dilakukan dengan melakukan penyesuaian secara interpersonal dalam melakukan interaksi atau komunikasi. Hal tersebut didasarkan pada observasi lapangan yang terjadi saat berinteraksi satu sama lain (Suheri 2019).

Berkaitan dengan hal diatas, peneliti akan mengkaji penerapan strategi akomodasi komunikasi dengan menggunakan Teori Akomodasi Komunikasi yang dikemukakan oleh Howard Giles (1973) dalam proses pembelajaran secara daring selama masa pandemi Covid-19 yang terjadi pada proses kegiatan belajar mengajar yang dilakukan oleh guru bahasa Inggris dengan siswanya secara daring selama masa pandemi Covid-19. Fenomena yang diangkat dalam penelitian ini berdasarkan dengan beberapa penelitian terdahulu yang berkaitan dengan penggunaan strategi akomodasi komunikasi dalam kegiatan belajar mengajar. 
Dalam penelitian yang dilakukan oleh Atalay di tahun 2015 yang meneliti aplikasi teori akomodasi komunikasi dalam pengajaran bahasa yang dilakukan oleh guru kepada muridnya. Penelitian yang dilakukan Atalay menguji penerapan teori akomodasi komunikasi yakni motivasi pembicara menyesuaikan pola bicara dan perilaku kepada orang lain melalui strategi konvergensi, divergensi dan akomodasi berlebih. Temuan dari penelitian tersebut adalah guru dalam melakukan akomodasi komunikasi terhadap muridnya perlu secara cermat dalam melakukan modifikasi terhadap bahan ajar kepada murid agar materi yang disampaikan dapat satu tingkat di atas kemampuan murid, contohnya dalam pengajaran menulis murid perlu diberikan pemahaman bahwa tulisan yang dibuat bertujuan untuk dipahami pembaca sehingga akan terdapat perbedaan ketika menulis untuk teman dibandingkan menulis untuk kegiatan akademis dan profesional; dalam pengajaran berbicara murid diberikan pemahaman pentingnya memahami pendengar bukan hanya dalam konteks tata bahasa tetapi juga dalam kelayakan berbicara (Atalay 2016).

Sementara itu dalam penelitian serupa di Tiongkok oleh Weizheng pada tahun 2019 yang berangkat dari permasalahan pembelajaran bahasa asing di Tiongkok dimana banyak murid di institusi tinggi masih belum fasih berbahasa Inggris padahal telah mempelajari bahasa Inggris lebih dari sepuluh tahun meskipun lulus tata bahasa dan kosakata tetapi, minimnya interaksi percakapan bahasa Inggris di ruang kelas menjadi faktor belum fasihnya kemampuan bahasa Inggris (Weizheng 2019). Padahal interaksi menggunakan bahasa asing di ruang kelas menjadi kunci untuk meningkatkan kemampuan berbahasa asing sehingga guru bahasa asing memiliki peran penting untuk mendorong penggunaan bahasa asing di kelas. Dalam riset tersebut, Weizheng menggunakan teori akomodasi komunikasi dengan melihat penggunaan konvergensi dan divergensi dari guru kepada murid (Weizheng 2019).

Penelitian yang dilakukan oleh Parcha di tahun 2014 menggunakan teori akomodasi komunikasi apakah melakukan konvergensi atau divergensi, tujuan dari riset Parcha yakni melihat akomodasi komunikasi yang akan dilakukan murid saat berinteraksi dengan murid lainnya dalam konteks penggunaan tagar (hashtag) untuk meningkatkan konvergensi dalam interaksi antar murid menggunakan media digital yakni twitter dimana para murid akan diarahkan untuk melakukan tweet menggunakan tagar yang telah disepakati dengan topik-topik misalnya kritik, topik, non-akademis maupun melakukan balasan atas tweet lain (Parcha 2014).

Terdapat juga penelitian yang mengkaji strategi akomodasi komunikasi di Bali, Indonesia pada mahasiswa Universitas Pendidikan Ganesha jurusan pendidikan bahasa Inggris menggunakan teori akomodasi komunikasi yang membagi akomodasi ke dalam konvergensi dan divergensi; penelitian ini berangkat dari kesadaran bahwa para mahasiswa pendidikan bahasa Inggris akan dipersiapkan menjadi guru yang membutuhkan kompetensi komunikasi (Suputra 2020).

Penelitian lainnya yang dilakukan di Indonesia terkait teori akomodasi komunikasi di ruang kelas adalah riset dari Nabila dkk yang meneliti motivasi guru dalam mengaplikasikan strategi akomodasi komunikasi di pelajaran bahasa Inggris. Menggunakan pendekatan kualitatif, riset yang dilakukan oleh Nabila dkk mengobservasi dan menggunakan wawancara terhadap para guru dalam melakukan pengajaran, hasilnya ditemukan bahwa strategi konvergensi lebih banyak diterapkan ketimbang divergensi (Nabila, Munir, and Anam 2020). Penggunaan strategi konvergensi dalam pengajaran bahasa Inggris antara lain berupa penggunaan kosakata yang lebih sederhana, pengulangan, menggunakan kode yang sama, penggunaan ejaan yang sama, pertukaran kode, menerjemahkan kata-kata yang sulit, mengembangkan topik, memperpanjang ucapan, penggunaan jeda, tersenyum, ekspresi wajah, menjaga gerak tubuh; sementara strategi 
divergensi antara lain mempertahankan bahasa yang digunakan, menunjukkan kode berbeda, mengganti topik, menggunakan ejaan yang berbeda, menggunakan kosakata yang rumit, tidak menunjukkan gerak tubuh ekspresif, dan merubah nada bicara (Nabila, Munir, and Anam 2020).

\section{TINJAUAN LITERATUR}

\section{Communication Accommodation Theory}

Teori akomodasi komunikasi merupakan pisau analisis untuk mengkaji perubahan yang dilakukan seseorang saat berkomunikasi dengan orang lain dalam berbagai ruang dan waktu termasuk perubahan bahasa, gaya ucapan, nada ucapan, kecepatan dan sebagainya, teori ini pertama kali dicetuskan dengan nama speech accomodation theory (1987) yang kemudian dikembangkan menjadi communication accomodation theory (Dainton 2019). Teori akomodasi komunikasi dapat menjadi pijakan untuk memahami bagaimana seseorang merubah perilaku komunikasi saat berinteraksi dengan orang lain termasuk alasan mengapa seseorang merubah perilaku komunikasinya. Giles selaku penggagas dari teori akomodasi komunikasi meyakini bahwa saat berinteraksi dengan orang lain maka individu akan merubah pola bahasa dan ucapannya dengan dua kondisi yakni kondisi pertama adalah menyamakan pola bahasa dan ucapan dari lawan bicara yang dikenal dengan istilah konvergensi atau membedakan pola bahasa dan ucapan dari lawan ucapan yang dikenal dengan istilah divergensi (Dainton 2019).

Asumsi dasar dari teori akomodasi komunikasi dalam riset yang dilakukan oleh Giles dan Coupland adalah individu berasal kelompok sosial yang berbeda-berbeda dan dapat dikelompokkan mulai dari etnisitas, gender, ras maupun agama dimana kelompok sosial ini membentuk identitas kolektif yang tertanam dalam diri masing-masing individu, bukan hanya itu, hal-hal lain seperti status pernikahan, afiliasi politik, karir juga merupakan kelompokkelompok sosial yang mempengaruhi cara individu menilai dirinya sendiri maupun penerimaan orang lain terhadap dirinya (Dainton 2019). Sebagai contoh, di Amerika Serikat yang terdiri dari banyak kelompok etnis, biasanya kelompok etnis minoritas memiliki kecenderungan untuk membangun satu komunitas untuk dapat berinteraksi dengan orang-orang yang satu etnis guna menjaga nilai-nilai etnis, praktik sosial maupun budaya yang ada (Vivero and Jenkins 1999). Selain itu, status perkawinan, sikap politik, pekerjaan dan ras mewakili kelompok sosial yang mempengaruhi cara untuk melihat diri sendiri dan cara orang melihat anda.

Kategorisasi muncul sebab manusia ingin menyederhanakan dan menciptakan makna atas kategori sehingga saat ini banyak kelompok identitas sosial yang muncul untuk merepresentasikan identitas, dalam kelompok identitas sosial terbagi atas kelompok dalam dan kelompok luar; dimana kelompok dalam merupakan tempat bagi individu merasa dirinya menjadi bagian didalamnya sedangkan kelompok luar menjadi tempat bagi individu merasa tidak menjadi bagian (Kurylo, 2012). Konsep kelompok dalam dan kelompok luar penting untuk memberikan pemahaman mendalam tentang teori akomodasi komunikasi sebab bahasa, ucapan dan pesan nonverbal menjadi pertanda dari status kelompok dalam dan kelompok luar seseorang, sebagai contoh orang dewasa yang berada di kelompok remaja kemungkinan besar akan merasa sebagai kelompok luar karena memiliki bahasa, ucapan, pesan nonverbal yang membedakan orang dewasa dengan remaja, contoh lain misalnya saat orang-tua berinteraksi dengan anak remajanya seringkali remaja menggunakan bahasa-bahasa yang tidak dipahami oleh orangtuanya yang menggambarkan perbedaan antara generasi orang-tua dengan generasi remajanya (Dainton 2019).

Selain terjadi di antar generasi, kelompok dalam dan keluar juga dapat muncul dalam perbedaan profesi misalnya saja dalam satu perusahaan yang sama namun berbeda departemen, 
orang-orang dari departemen TI (teknologi informasi) mungkin dalam berinteraksi dengan orang-orang departemen lain akan menggunakan istilah-istilah yang membingungkan atau sulit dipahami meskipun, tidak ada unsur kesengajaan karena bisa saja orang-orang dari departemen TI memang lazimnya menggunakan istilah tersebut dalam berkomunikasi namun, hal ini dapat membuat orang-orang departemen non-TI merasa terintimidasi sebab tidak memiliki pemahaman atas istilah yang digunakan orang departemen TI, oleh sebab itu dalam menggunakan berbagai istilah harus cermat terutama saat berkomunikasi dengan orang dari kelompok luar (Dainton 2019).

Manusia mengatur pola bahasa dan ucapannya baik untuk mengasimilasikan dirinya dengan orang lain ataupun untuk mendeviasikan diri dengan orang lain sebagaimana diargumentasikan bahwa kemampuan mengatur pola bahasa dan ucapan ini merupakan bagian fundamental dari interaksi yang berhasil (Giles \& Gasiorek, 2014). Asumsi dasar dari teori akomodasi komunikasi adalah jika seseorang ingin menjadi bagian atau dianggap sebagai kelompok dalam maka dirinya akan mengambil perilaku akomodasi dengan konvergensikan dirinya sesuai kelompok identitas sosial tersebut, hal-hal yang akan diakomodasi termasuk ucapan, perilaku, pilihan kata, gaya bicara, hingga gestur seperti senyum, seseorang yang disukai, karismatik dan memiliki kemampuan sosial yang baik akan semakin mungkin untuk menyesuaikan diri dengan pola komunikasi lawan bicara atau kelompok (Dainton 2019).

Namun, terdapat pula kondisi saat seseorang tidak ingin terasosiasi dengan kelompok identitas sosial tertentu sehingga ingin membedakan dirinya dengan kelompok identitas sosial tersebut sehingga dalam kondisi demikian seseorang akan membedakan dirinya melalui divergensi yakni alih-alih menyamakan pola komunikasi justru yang dilakukan adalah memperjelas perbedaan yang ada misalnya seorang guru taman kanak-kanak yang akan menggunakan nada bicara tinggi saat mendisiplinkan anak didiknya, atau dalam konteks lain divergensi dilakukan untuk mempertahankan satu identitas kebudayaan seperti orang yang menggunakan aksen Skotlandia meski tinggal di Amerika Serikat ataupun untuk mempertahankan identitas status seperti dokter yang menggunakan istilah medis saat bicara dengan pasien (Dainton 2019).

Selain konvergensi dan divergensi, terdapat opsi lain sebagai perpanjangan teori akomodasi komunikasi untuk menjelaskan keberhasilan ataupun kegagalan interaksi, opsi tersebut yang pertama adalah mempertahankan/maintenance yang secara harfiah yakni kekosongan penyesuaian diri atau tidak melakukan akomodasi, kondisi dapat muncul karena orang dari kelompok luar tidak menyadari adanya perbedaan antara dirinya dengan orang lain yang berada di kelompok dalam atau dapat juga terjadi jika orang dari kelompok luar tidak peduli atau tidak dapat melakukan penyesuaian (Giles \& Ogay, 2007); opsi lainnya adalah perilaku non akomodatif yang terdiri dari akomodasi berlebihan dan kurangnya akomodasi dalam interaksi hal ini tergolong sebagai evaluasi subjektif tergantung penilaian masing-masing orang misalnya dalam kondisi seorang dokter menyederhanakan terminologi yang digunakan saat berbicara dengan pasien dan pendamping, mungkin saja pasien merasa senang karena sang dokter mengkonvergensikan dirinya menggunakan bahasa yang dipahami oleh pasien tapi, sang pendamping bisa menilai hal tersebut sebagai merendahkan, dalam kondisi ini upaya yang dilakukan dokter untuk menyederhanakan bahasanya dilihat sebagai konvergensi sementara sang pendamping melihat upaya dokter menyederhanakan bahasa sebagai perilaku akomodasi berlebih yang tergolong non akomodatif (Giles \& Gasiorek, 2014). 


\section{METODE PENELITIAN}

Penelitian ini menggunakan pendekatan kualitatif dengan metode eksploratif yang digunakan untuk membahas kemungkinan suatu fenomena baru yang belum ditemukan dalam penelitian sebelumnya (Mudjiyanto 2018).

Subjek Penelitian

Subjek penelitian dalam penelitian ini adalah empat guru bahasa Inggris di Sekolah Dasar, Sekolah Menengah Pertama, Sekolah Menengah Atas dan Sekolah Menengah Kejuruan yang berlokasi di Jakarta. Keempat guru tersebut berasal dari empat sekolah dan tingkatan yang berbeda, antara lain; narasumber satu adalah guru bahasa Inggris di SD Silaturahim Boarding School, narasumber dua adalah guru bahasa Inggris di tingkat menengah pertama bernama Al Hamid Boarding School, narasumber ketiga adalah guru bahasa Inggris di tingkat menengah atas Yayasan Pendidikan Islam Alkenaniyah dan narasumber keempat adalah guru bahasa Inggris di SMK Pasar Minggu. Penentuan subjek penelitian dalam penelitian ini didasari oleh tujuan peneliti dalam pemecahan masalah penelitian dan ditentukan peneliti berdasarkan narasumber yang dianggap paling mengetahui dan mengalami langsung fenomena yang sedang diteliti yaitu bagaimana menerapkan strategi akomodasi komunikasi pada pembelajaran daring selama masa pandemic Covid-19. Maka dari itu, peneliti menentukan subjek penelitian yaitu guru-guru dari Sekolah Dasar sampai Sekolah Menengah Atas dan difokuskan dalam pembelajaran Bahasa Inggris yang berlokasi di daerah Jakarta agar lebih spesifik dan belum pernah ada pada penelitian lainnya.

Teknik Pengumpulan Data

Dalam penelitian ini, peneliti menggunakan data primer dan data sekunder sebagai teknik pengumpulan data. Adapun teknik pengumpulan data primer yang dilakukan oleh peneliti adalah dengan teknik wawancara mendalam secara terstruktur yang dilakukan melalui e-mail dan zoom meeting berdasarkan daftar pertanyaan yang telah dipersiapkan oleh peneliti sebelum wawancara berlangsung. Teknik wawancara dilakukan oleh peneliti dengan menggunakan empat narasumber untuk mengasah data yang telah ditemukan, yaitu guru bahasa inggris tingkat SD, SMP, SMA dan SMK yang berlokasi di Jakarta. Kemudian, teknik pengumpulan data sekunder yang digunakan oleh peneliti adalah dengan mencari data pendukung dari buku, internet dan penelitian-penelitian terdahulu yang didapat melalui jurnal online. Kemudian, teknik konfirmasi data yang dilakukan oleh peneliti dalam penelitian ini adalah dengan cara triangulasi yang mana dilakukan dengan cara menggabungkan hasil wawancara dengan hasil-hasil dari penelitian dalam jurnal terdahulu (Jaya, 2020).

\section{HASIL DAN PEMBAHASAN}

Dalam teori akomodasi komunikasi setiap orang memiliki pola bahasa, ucapan dan bahasa non-verbal yang berbeda-beda tergantung kelompok identitas sosial tempatnya berasal, kelompok identitas sosial antara lain dari kelompok etnis, pekerjaan, status perwakilan, afiliasi politik dan lainnya (Dainton, 2019). Dalam melakukan interaksi sosial, seseorang dapat merasa menjadi bagian dari satu kelompok yang dikenal dengan istilah kelompok dalam/in-group ataupun merasa tidak menjadi bagian dari satu kelompok dengan istilah kelompok luar/out-group sehingga ketika seseorang dari kelompok identitas sosial yang berbeda saling berinteraksi dengan orang lain, terdapat empat strategi akomodasi komunikasi yang mungkin dilakukan antara lain pertama adalah konvergensi yakni menyesuaikan pola komunikasi dengan lawan bicara atau kelompok identitas sosial; kedua adalah divergensi yakni membedakan pola komunikasi dengan lawan bicara atau kelompok identitas sosial (Dainton, 2019); ketiga adalah 
mempertahankan/maintenance yakni tidak melakukan akomodasi karena tidak sadar ataupun karena perilaku acuh (Giles \& Ogay, 2007) keempat adalah non-akomodatif yakni akomodasi berlebihan ataupun kurang akomodasi yang merupakan penilaian subyektif dari lawan bicara atau kelompok identitas sosial misalnya karena merasa direndahkan (Giles \& Gasiorek, 2014).

Dalam penelitian terdahulu misalnya dari penelitian Atalay pada tahun 2016 yang meneliti akomodasi komunikasi oleh guru terhadap murid dalam pengajaran bahasa asing disimpulkan bahwa konvergensi dan divergensi akan muncul ketika penutur bahasa asli (native) akan menyesuaikan pola bicara dan perilakunya saat berkomunikasi dengan penutur bahasa tidak asli (non-native), dalam konteks guru dan murid ditemukan bahwa untuk memberikan pemahaman kepada murid tentang menulis dan berbicara, guru terlebih dahulu akan menyesuaikan pola bicara dan perilakunya agar bisa dipahami murid dengan melakukan konvergensi untuk mendorong kesadaran belajar murid (Atalay 2016).

Di Tiongkok dalam penelitian yang dilakukan oleh Weizheng tahun 2019 mengkaji akomodasi komunikasi oleh guru terhadap murid dalam pengajaran bahasa Inggris menemukan bahwa dalam interaksi di ruang kelas antara guru dan murid, guru akan melakukan strategi akomodasi komunikasi, adapun akomodasi komunikasi yang dilakukan oleh para guru adalah dengan melakukan pendekatan; interpretasi kemampuan murid seperti tatapan mata, kontrol topik, mengajukan pertanyaan referensial, perbaikan percakapan dan umpan balik; ekspresi emosional dan kontrol interpersonal; temuan dari penelitian tersebut adalah semakin sering akomodasi komunikasi dilakukan maka interaksi di kelas akan semakin baik (Weizheng 2019).

Sementara dalam riset yang dilakukan oleh Parcha di tahun 2014 dalam penelitian yang mengamati penggunaan tagar di twitter untuk mendorong akomodasi komunikasi dalam interaksi antar murid, hasil dari penelitian tersebut menemukan penggunaan tagar meningkatkan konvergensi dalam interaksi antar murid baik secara akademis maupun non-akademis, para murid berinteraksi secara lebih dalam dan bermakna yang berujung pada meningkatnya pemahaman murid atas materi pembelajaran bahkan terdapat hal-hal positif yang dirasakan para murid seperti senang didorong berinteraksi di luar ruang kelas sehingga teman-teman di kelas terasa bagaikan komunitas, menyenangkan karena bisa mempelajari hal baru dan mengenal teman kelas lebih dekat, membantu murid dalam pengerjaan tugas (Parcha 2014).

Dalam riset yang meneliti akomodasi komunikasi di mahasiswa pendidikan bahasa Inggris Universitas Pendidikan Ganesha pada tahun 2020, secara kualitatif penelitian tersebut menemukan bahwa mahasiswa dalam berinteraksi menggunakan strategi konvergensi dalam variabel kecapatan berbicara, pengakhiran kalimat, kepanjangan bicara, sementara variabel leksikal (pilihan kata) dilakukan secara konvergensi oleh seluruhnya dan secara divergensi oleh tiga puluh tiga persen (Suputra 2020). Adapun motivasi melakukan konvergensi dalam akomodasi komunikasi dalam riset ini mengacu pada Giles antara lain pembicara ingin mendorong persetujuan sosial, pembicara ingin mencapai efisiensi dalam komunikasi, pembicara ingin dianggap lebih menarik oleh lawan bicara dalam berkomunikasi (Giles 2016).

Penelitian lain yang meneliti akomodasi komunikasi dalam pengajaran bahasa Inggris oleh guru dengan murid di Indonesia dilakukan oleh Nabila dkk tahun 2020 menemukan bahwa motif dari para guru dalam akomodasi komunikasi adalah motivasi afektif untuk membangun kedekatan dengan murid sebab ditemukan para murid terkadang mengalami ketakutan untuk menjawab percakapan dari guru bahasa Inggris karena minimnya kemampuan bahasa Inggris yang dimiliki; motivasi lainnya yakni kognitif guna meningkatkan pemahaman murid di kelas misalnya di awal guru menyampaikan materi dalam bahasa Inggris tapi kemudian merubah kode dengan menyampaikan ulang dalam bahasa Indonesia agar murid memiliki pemahaman, hal 
lainnya guru juga menerjemahkan kata-kata yang sulit agar lebih dipahami oleh siswa, dalam prakteknya para guru lebih dominan menggunakan strategi konvergensi ketimbang divergensi di pelajaran bahasa Inggris (Nabila, Munir, and Anam 2020).

Dalam penelitian ini, peneliti ingin mengetahui bagaimana proses akomodasi komunikasi antara guru bahasa inggris dan murid. Dalam proses akomodasi komunikasi, khususnya pada pembelajaran bahasa, tidak semua hal terutama pada guru dan murid tidak selalu menggunakan strategi konvergensi, terkadang guru juga memaksakan untuk melakukan strategi divergensi. Di Indonesia, sama seperti penelitian sebelumnya yang dilakukan di negara Tiongkok yang mana segala informasi yang diberikan menggunakan bahasa Indonesia, begitupula dalam percakapan sehari-hari dan sistem kurikulum di Indonesia dalam pelajaran bahasa Inggris, lebih banyak diuji secara tertulis. Kemudian, yang menjadi hambatan lain dalam pembelajaran bahasa Inggris di Tiongkok adalah kurangnya interaksi menggunakan bahasa Inggris di kelas bahasa Inggris itu sendiri. Ketika siswa tidak mengerti, maka guru akan menerjemahkan dengan bahasa Tiongkok, tujuannya adalah ingin melakukan konvergensi atau penyesuaian diri. Sedangkan dalam penelitian lain, yang terjadi di Surabaya juga melakukan hal yang sama, yaitu melakukan akomodasi komunikasi dalam bentuk konvergensi. Contohnya ketika ada kosa kata yang sulit, guru akan langsung menerjemahkan ke dalam bahasa asal negaranya dan dari nada bicaranya dilakukan perlahan dan berbicara dengan intonasi cepat seperti yang dilakukan para native bahasa Inggris. Selain itu, dalam strategi divergensi, para guru cenderung memaksakan agar para murid mengerti bahasa Inggris tanpa diterjemahkan. Kemudian ketika murid bertanya, guru cenderung merekomendasikan murid untuk mencari tahu sendiri hal yang belum dimengerti oleh murid.

Hasil penelitian yang dilakukan peneliti menunjukan bahwa kegiatan belajar mengajar yang dilakukan oleh sekolah-sekolah di Jakarta baik SD, SMP, SMA maupun SMK semenjak adanya pandemi Covid-19 kegiatan belajar mengajar mengalami perubahan, yaitu yang dahulu dilakukan secara langsung dengan pertemuan tatap muka, namun saat ini dilakukan dengan sistem pembelajaran daring. Transisi proses kegiatan belajar mengajar tersebut mengakibatkan beberapa guru sulit melakukan pendekatan personal kepada para murid. Berdasarkan hasil wawancara yang dilakukan oleh peneliti, ditemukan bahwa akibat pembelajaran secara daring ini, sulit melakukan pendekatan personal antara guru dan murid karena waktu belajar mengajar secara daring dilakukan lebih singkat dibandingkan saat pertemuan tatap muka. Padahal menurut narasumber 1, pendekatan dan hubungan personal antara guru dan murid paling penting untuk dilakukan agar proses penyampaian materi lebih mudah diterima dan tidak terlalu berfokus kepada textbook. Hal tersebut juga dibenarkan oleh narasumber 2 dan 3 yang mana ditemukan fakta bahwa pada kenyataannya akibat sulitnya melakukan pendekatan personal, mengakibatkan guru sulit untuk memahami karakteristik dari masing-masing murid dan dalam proses penyampaian materi ada murid yang langsung mengerti dan ada yang tidak.

Berkaitan dengan proses penyampaian materi, kegiatan belajar mengajar meskipun dilakukan secara daring, berdasarkan hasil wawancara keempat narasumber yang dilakukan oleh peneliti, para guru bahasa Inggris ini masih dapat melihat murid satu sama lain, apakah murid tersebut memperhatikan proses belajar mengajar atau tidak yaitu dengan menggunakan aplikasi Zoom Meeting. Kemudian untuk penyampaian bahan materi, pemberian rekaman Zoom Meeting dan untuk latihan serta pengumpulan tugas, semua narasumber menggunakan aplikasi Google Classroom. Ada tambahan aplikasi dan website dari narasumber 2 yang mana adalah guru bahasa Inggris SMP Pondok Pesantren Al Hamid, yaitu menggunakan website internal sekolah bernama El Mantap (www.alhamid.sch.id) untuk memberikan informasi mengenai pembelajaran, 
absensi kelas, data profil murid, dan dapat digunakan juga untuk mengumpulkan tugas-tugas sekolah. Selain itu, narasumber 4 yang mana adalah guru bahasa Inggris SMA Madrasah Aliyah Al-Kenaniyah, selain menggunakan Zoom Meeting, juga menggunakan Whatsapp Group untuk pemberian tugas dan e-mail untuk pengumpulan tugas. Metode pembelajaran dengan menggunakan beberapa media yang telah disebutkan sebelumnya, menggunakan bahan materi ajar bahasa Inggris sesuai dengan kurikulum yang berlaku, yang mana keempat narasumber menggunakan referensi buku sesuai dengan kebijakan masing-masing sekolah. Materi bahasa Inggris yang diajarkan baik tingkatan SD, SMP, SMA maupun SMK adalah Listening, Speaking, Reading dan Writing dengan cara pengajaran yang berbeda tergantung tingkatan pembelajarannya. Berdasarkan hasil wawancara dengan narasumber 1, pada tingkatan SD kelas 1-3 cara pengajaran lebih dilakukan dengan metode fun learning yaitu lebih banyak dilakukan dengan bernyanyi bersama, bermain games bersama, penambahan kosakata dasar dan belum berfokus kepada penggunaan grammar. Sedangkan pada tingkatan SD kelas 4-6 metode pembelajaran lebih kepada pendalaman materi dan latihan soal. Kemudian pada narasumber 2, pada tingkatan SMP cara mengajar menggunakan presentasi PowerPoint yang disajikan dengan colorful agar tidak membosankan dan monoton. Lalu pada narasumber 3, pada tingkatan SMK digunakan cara mengajar yang sedikit berbeda yaitu selain dengan Zoom Meeting, namun juga dengan cara pembuatan video masing-masing murid untuk mempraktekan dan menilai gestur tubuh, ekspresi wajah, cara bicara dari segi pronunciation, grammar dan penggunaan verbs. Selain itu juga menggunakan Voice Note dalam aplikasi whatsapp untuk mengetahui kelancaran murid dalam berbicara bahasa Inggris.

Keempat narasumber merasakan kelebihan dan kekurangan dari metode pembelajaran baru selama pembelajaran daring. Keempat narasumber merasakan kelebihan dari metode pembelajaran ini adalah cara pengajaran yang lebih fleksibel dan tidak banyak aktivitas fisik yang dilakukan seperti kegiatan belajar mengajar secara tatap muka, karena guru hanya mengajar dari rumah dan melalui alat bantu laptop. Sementara untuk kekurangan yang dirasakan adalah penyampaian materi ajar menjadi kurang maksimal dan siswa cenderung pasif dalam menanggapi pembelajaran. Berkaitan dengan hal tersebut, agar penyampaian pembelajaran bahasa Inggris dapat diterima dengan baik oleh peserta didik, keempat narasumber melakukan strategi proses akomodasi yang mana keempat narasumber tersebut menggunakan strategi akomodasi konvergensi demi kelancaran belajar mengajar.

Strategi konvergensi yang dilakukan oleh narasumber 1, yang mana adalah guru tingkat SD melakukan penyesuaian cara belajar mengajar tergantung dengan tipe anak murid, dikarenakan SD Silaturahim Islamic School merupakan gabungan murid reguler dan berkebutuhan khusus, maka narasumber 1 melakukan penyesuaian dan tindakan yang berbeda satu sama lain. Maksudnya berbeda adalah dengan melakukan penyesuaian dengan gaya belajar murid dan membedakan cara penyampaian gaya bahasa dan gaya bicara. Untuk anak berkebutuhan khusus, cara belajar dan cara penyampaian lebih personal, lebih lembut dan lebih perlahan. Selain itu, untuk anak berkebutuhan khusus pihak sekolah menyediakan adanya shadow teacher untuk mendampingi kegiatan belajar di rumah. Shadow teacher merupakan guru tambahan diluar guru pengajar di sekolah yang ditugaskan untuk mendampingi murid dalam belajar secara daring. Strategi konvergensi juga dilakukan dengan cara memberikan jadwal visit belajar secara langsung di sekolah untuk menyesuaikan cara pembelajaran anak berkebutuhan khusus karena murid berkebutuhan agak sulit melakukan proses pembelajaran jika belum mengenal lawan bicaranya. 
Narasumber 2, 3 dan 4 juga melakukan penyesuaian cara belajar para murid. Jika murid masih belum mengerti mengenai bahan materi yang diajarkan, maka akan diulangi lagi sampai mengerti dengan cara menyesuaikan gaya bicara dan memperlambat intonasi bicara sampai murid mengerti apa yang diajarkan. Kemudian, berdasarkan hasil wawancara yang dilakukan oleh peneliti, narasumber juga menggunakan orang ketiga seperti wali kelas dan guru lainnya untuk mengetahui karakteristik masing-masing anak agar mengetahui bagaimana cara penyampaian materi yang sesuai dengan masing-masing anak. Hal tersebut dibutuhkan agar murid merasa nyaman dan tidak merasa canggung untuk berinteraksi di dalam kelas serta agar mempermudah murid untuk mengerti materi yang diajarkan.

Dari pengalaman narasumber menggunakan strategi konvergensi dalam proses akomodasi komunikasi, ditemukan fakta bahwa muncul dampak kepercayaan diri murid terhadap percakapan bahasa Inggris dan memberikan pengaruh keaktifan murid selama kegiatan belajar mengajar secara daring berlangsung. Berdasarkan pengalaman yang dialami oleh Narasumber 1, meskipun sudah dilakukan penyesuaian dari segi komunikasi, cara bicara dan cara belajar murid, murid masih cenderung tidak berani berbicara banyak ketika berinteraksi di kelas. Maka dari itu, digunakan strategi lain dengan membuat sesi classroom language setiap kelas daring berlangsung yang mana pada sesi tersebut para siswa diwajibkan untuk menggunakan full english, seperti ketika mereka ingin izin minum, izin ke toilet, izin bertanya, atau ketika murid ingin melakukan interupsi kelas. Selain itu, pada saat proses belajar mengajar, jika ada materi yang belum dimengerti, murid boleh bertanya menggunakan bahasa Indonesia dan guru masih melakukan pemberian materi dengan melakukan mix bahasa yaitu mencampurkan penjelasan bahasa Inggris kemudian mengartikan ke bahasa Indonesia.

Tidak jauh berbeda dengan pengalaman pada narasumber 2 sebagai guru SMP, narasumber 2 mengatakan bahwa jika murid dipaksakan berbicara menggunakan bahasa Inggris di kelas, mereka akan cenderung pasif dan merasa tidak percaya diri akan kemampuan bahasa Inggrisnya, karena mereka beranggapan bahwa teman-temannya akan mengejek jika menggunakan bahasa Inggris. Maka dari itu, dalam pembelajaran di kelas masih dilakukan pengajaran mix bahasa seperti yang dilakukan narasumber 1. Berbeda pada tingkatan SMK berdasarkan pengalaman narasumber 3 bahwa kepercayaan diri murid SMK dalam berbicara bahasa inggris sudah muncul, namun tetap para murid masih merasa demam panggung ketika guru menanyakan dalam bahasa Inggris. Saat mereka menjawab, rata-rata murid diam terlebih dahulu untuk berpikir kosakata apa yang dipakai dan murid mayoritas pasif karena takut salah dalam pengucapan.

Meskipun sudah dilakukan strategi akomodasi dalam kegiatan belajar mengajar secara daring, para pengajar baik tingkat SD, SMP, SMA dan SMK juga merasakan hambatan dalam penyesuaian cara mengajar kepada para murid. Berdasarkan hasil wawancara yang dilakukan oleh peneliti, seluruh narasumber merasakan bahwa semenjak pembelajaran daring meskipun sudah dilakukan penyesuaian namun pada kenyataannya, siswa tidak sepenuhnya paham dengan materi pembelajaran yang diajarkan di kelas dan para guru belum mengenal dan belum mengetahui karakteristik secara personal masing-masing siswa. Selain itu, para murid masih pasif dalam berinteraksi di kelas karena kurangnya kepercayaan diri dalam berkomunikasi menggunakan bahasa Inggris. Padahal berdasarkan pengalaman para narasumber, dengan melakukan latihan terus menerus baik latihan soal atau belajar bahasa inggris dengan berbagai kegiatan lain yang menyenangkan yaitu dengan menonton video tanpa subtitle, bermain games bahasa Inggris dan mengeksplor bahasa itu sendiri dapat menambah kemampuan bahasa Inggris yang dimiliki. Seperti yang terdapat dalam kelas narasumber 1 bahwa terdapat murid yang mana 
adalah seorang gamers dan murid tersebut kemampuan bahasa Inggrisnya lebih dibandingkan teman-temannya yang lain.

\section{KESIMPULAN}

Dalam kegiatan belajar mengajar selama pandemi Covid-19, membuat para pengajar memikirkan strategi yang tepat untuk digunakan agar proses kegiatan belajar mengajar berjalan dengan lancar. Berdasarkan hasil penelitian yang dilakukan oleh peneliti dengan metode wawancara, para pengajar mayoritas menggunakan strategi konvergensi dengan melakukan penyesuaian cara belajar, cara penyampaian pesan, dan cara akomodasi komunikasi terhadap siswa. Selain itu, terdapat pula strategi lain dan dampak yang dirasakan oleh perserta didik akibat perubahan metode pembelajaran yang semula tatap muka namun menjadi pembelajaran daring. Hal tersebut menyebabkan, murid cenderung sulit mengerti mengenai materi yang diajarkan dan cenderung pasif dalam berinteraksi serta menanggapi guru ketika pembelajaran berlangsung.

Penelitian ini menunjukkan bagaimana strategi akomodasi komunikasi dalam kegiatan belajar mengajar selama pandemi Covid-19 yang dilakukan oleh para pengajar bahasa Inggris pada tingkat SD, SMP, SMA dan SMK. Serta bagaimana dampak dan hambatan yang dirasakan dalam proses pembelajaran. Penelitian selanjutnya dapat melakukan pembahasan yang serupa namun pada tingkat Universitas atau pada kegiatan Work From Home.

\section{DAFTAR PUSTAKA}

Anugrahana, Andri. 2020. "Hambatan, Solusi Dan Harapan: Pembelajaran Daring Selama Masa Pandemi Covid-19 Oleh Guru Sekolah Dasar." Scholaria: Jurnal Pendidikan Dan Kebudayaan 10 (3): 282-89. https://doi.org/10.24246/j.js.2020.v10.i3.p282-289.

Atalay, Ozlem. 2016. “Accommodation Theory and Language Teaching Özlem Atalay,” no. January.

Cathrin, Shely. et al. 2020. "Empat Papan: Etika Komunikasi Di Media Sosial Dalam Perspektif Budaya Jawa.” Jurnal Lensa Mutiara Komunikasi 4: 165-83.

Dainton, Marianne. 2019. Applying Communication Theory for Professional Life. 4th ed. Thousand Oaks: SAGE Publications, Inc.

Dwina, Irma. 2020. "Melemahnya Ekonomi Indonesia Akibat Covid-19.” Socarxiv Papers, 1-5. https://www.kompasiana.com/dewilst08/5ebcb675097f3659853413b3/ekonomi-indonesiamenanggung-beban-covid-19.

Fahmi, Muhammad Hanif. 2020. "KOMUNIKASI SYNCHRONOUS DAN ASYNCHRONOUS DALAM E-LEARNING PADA MASA PANDEMIC COVID-19.” Jurnal Nomosleca 6 (April): 68-76.

Fatmawati, Umi. 2020. "Pemahaman Covid-19 Dan Dampaknya Terhadap Proses Pembelajaran Daring Selama Pandemi Bagi Mahasiswa Prodi Farmasi Fakultas Ilmu Kesehatan Dan Sains Universitas PGRI Madiun Umi." Prosiding SENFIKS (Seminar Nasional Fakultas Ilmu Kesehatan Dan Sains) 1 (1): 48-66.

Giles, H., \& Gasiorek, J. 2014. "Parameters of Nonaccommodation: Refining and Elaborating Communication Accommodation Theory." In J. P. Forgas, O. Vincze, \& J. László (Eds.), Sydney Symposium of Social Psychology. Social Cognition and Communication 8 (1): 155. https://doi.org/10.2307/832136. 
Giles, H. \& Ogay, T. 2007. "Accomodating A New Frontier: The Context of Law Enforcement. Dalam K. Fiedler.” Social Communication, 21-27. https://doi.org/10.1075/hoph.7.02cou.

Giles, Howard. 2016. "The Social Origins of Cancer." Communication Accomodation Theory: Negotiating Personal Relationships and Social Identities Across Context 8 (10): 54-55. https://doi.org/10.1080/00091383.1976.10569002.

Hia Setiamenda, Niscaya; Ginting. 2018. "Pengaruh Internet Terhadap Prestasi Belajar Mahasiswa Fakultas Ekonomi Dan Ilmu Sosial Universitas Sari Mutiara Indonesia Kota Medan." JURNAL LENSA MUTIARA KOMUNIKASI 1 (Vol 1 No 1 (2018): JURNAL LENSA MUTIARA KOMUNIKASI): 61-77. http://e-journal.sarimutiara.ac.id/index.php/JLMI/article/view/561.

Jaya. 2020. Metode Penelitian Kuantitatif dan Kualitatif. Jogyakarta: Quadrant

Kurylo. 2012. Inter/Cultural Communication: Representation and Construction of Culture in Everyday Interaction. California, Amerika Serikat: SAGE Publications

Menkes. 2020. "Keputusan Menteri Kesehatan Republik Indonesia Nomor HK.01.07/MenKes/413/2020 Tentang Pedoman Pencegahan Dan Pengendalian Corona Virus Disease 2019 (Covid-19)." MenKes/413/2020 2019.

Mudjiyanto, Bambang. 2018. "Tipe Penelitian Eksploratif Komunikasi." Jurnal Studi Komunikasi Dan Media 22 (1): 65. https://doi.org/10.31445/jskm.2018.220105.

Nabila, Almas Rizkika, Ahmad Munir, and Syafi'ul Anam. 2020. “Teacher' S Motives in Applying Communication Accommodation" 3 (2015): 373-84.

Parcha, Joshua M. 2014. "Accommodating Twitter: Communication Accommodation Theory and Classroom Interactions." Communication Teacher 28 (4): 229-35. https://doi.org/10.1080/17404622.2014.939671.

Ristyawati, Aprista. 2020. "Efektifitas Kebijakan Pembatasan Sosial Berskala Besar Dalam Masa Pandemi Corona Virus 2019 Oleh Pemerintah Sesuai Amanat UUD NRI Tahun 1945." Administrative Law and Governance Journal 3 (2): 240-49. https://doi.org/10.14710/alj.v3i2.240-249.

Suheri. 2019. “Akomodasi Komunikasi.” Universitas Dharmawangsa 2 (1): 2569-6446.

Suputra. 2020. "The Analysis Of Communication Accommodation Strategies Used By Students Of English Language Education Of Ganesha Univeristy Of Education” 8 (1): 5-12.

Vivero, V. N., and S. R. Jenkins. 1999. "Existential Hazards of the Multicultural Individual: Defining and Understanding 'Cultural Homelessness."' Cultural Diversity and Mental Health 5 (1): 6-26. https://doi.org/10.1037/1099-9809.5.1.6.

Weizheng, Zheng. 2019. "Teacher-Student Interaction in EFL Classroom in China: Communication Accommodation Theory Perspective." English Language Teaching 12 (12): 99. https://doi.org/10.5539/elt.v12n12p99. 